\title{
Biological value in milk-protein concentrates with malt ingredients
}

\section{Olena Grek, Olena Onopriichuk, Alla Tymchuk}

\author{
National University of Food Technologies, Kyiv, Ukraine
}

\section{Keywords:}

Milk

Protein

Malt

Amino acid

\section{Article history:}

Received 04.02.2019

Received in revised form 02.06.2019

Accepted 30.09.2019

Corresponding author:

Olena Onopriichuk

E-mail:

olena.onopriychuk@ gmail.com

DOI: $10.24263 / 2304-$

974X-2019-8-3-13

\section{Abstract}

Introduction. It is actual to study of biological value of milk-protein concentrates with malt ingredients. Biological value characterizes the quality of the protein composition with the ability to evaluate it according to physiological norms.

Materials and methods. Milk protein concentrates without and with malt ingredients used for research. The biological value and amino acid composition of the samples was determined by ion exchange chromatography on LC 3000 automatic analyzer. Protein digestibility in vitro was determined by hydrolysis of samples using a solution of $6 \mathrm{~N}$ hydrochloric acid at a temperature of $(120 \pm 2){ }^{\circ} \mathrm{C}$ for 24 hours.

Results and discussion. The total amino acid content in milk protein concentrates with malt ingredients increased compared to control due to the addition of germinated cereals (wheat, barley, oats, corn).

The amino acid score for the studied samples has been calculated. When preparing the mixture: milk-protein concentrate + malt ingredients, the content of limiting amino acids increases - methionine + cystine and threonine. Biological value of the experimental samples is increased. So, with wheat malt this indicator is $65.82 \%$, barley $65.57 \%$, oat $-64.11 \%$, corn $-63.95 \%$, while for control purposes the value is fixed at $62.84 \%$. The rationality coefficient of amino acid composition is $0.74 \pm 0.12$, which is $3 \%$ higher than in milk protein concentrate obtained by traditional technology.

The in vitro digestibility of proteins under the action of enzymes (pepsin + trypsin) with the introduction of malt ingredients in milk protein concentrates is accelerated. This is due to previous hydrolysis and destruction of protein substances during malting of cereals.

Conclusion. Milk protein concentrates with malt ingredients have an increased biological value of 1.11$2.98 \%$. 


\begin{abstract}
Abbreviation
AAS - amino acid score

EAA - essential amino acids

MPC - milk-protein concentrate

NAA - nonessential amino acids
\end{abstract}

\title{
Introduction
}

The modern term "biological value" refers to the level of efficient use of protein by the body, which is spent on maintaining nitrogen balance in the body [1]. It depends on the amino acid composition, the balance of amino acids and structural features. Given these premises, this indicator characterizes the quality of the protein composition in the food product with the ability to evaluate it according to physiological norms [2].

It is important not only when assessing biological value the presence of all the essential amino acids (EAA) in the product, their high content, but also the quantitative balance in accordance with the FAO/WHO standards [3]. EAA discrepancy in quantitative characteristics of the amino acid scale of an ideal protein indicates an imbalance in the product - a decrease in its biological value [4].

According to the FAO/WHO scale, an ideal protein contains nonessential amino acids (NAA) $(\mathrm{mg} \% / 100 \mathrm{~g}$ protein): isoleucine -4 , leucine -7 , lysine -5.5 , methionine + cystine -3.5 , phenylalanine + tyrosine -6 , tryptophan -1 , threonine -4 , valine $-5[5,6]$.

Replaceable amino acids such as cystine and cysteine are synthesized if there is a sufficient amount of methionine, an essential amino acid, the amount of which depends entirely on food intake [7].

Milk protein concentrates with malt ingredients differ in their chemical composition from traditional ones by enrichment with functional and technological components. In this regard, when determining the biological value of such products as a criterion for the quality of a protein, it is necessary to take into account the characteristics of the amino acid composition of animals and plant proteins and the degree of their digestibility after digestion $[8,20]$. Animal proteins are complete, while vegeTable proteins, because of the relatively low content of lysine, tryptophan, threonine in them, are not. Such features must be taken into account when combining proteins of different origins in dairy products in order to balance the amino acid composition [9, 10]. For example, an insufficient amount of sulfurcontaining amino acids in casein is compensated by their content in malt proteins [11].

The aim of research is determination of biological value of milk-protein concentrates in compared with milk-protein concentrate obtained by traditional technology.

\section{Materials and methods}

\section{Materials}

Object of research - milk-protein concentrates without and with malt ingredients. Milkprotein concentrate (base) was obtained by the acid-rennet method from pasteurized skim milk at a temperature of $(78 \pm 2){ }^{\circ} \mathrm{C}$ with an durationof $20 \ldots 30 \mathrm{~s}$. Further, milk ripening was at a temperature of $(30 \pm 1)^{\circ} \mathrm{C}$ by pure cultures of hetero-and homoenzymatic microorganisms Lactococcuslactis subsp. lactis, Lactococcuslactis subsp. cremoris, Lactococcuslactis subsp. Acetoinicus. In addition to the starter culture, a $40 \%$ solution of calcium chloride and a milk- 


\section{- Food Technology —}

clotting enzyme preparation were added. Fermentation was carried out until a clot was obtained with an acidity of $(75 \pm 5)^{\circ} \mathrm{T}$. The separation of whey from the clot was carried out to a moisture content $(78 \pm 2) \%$. Milk-protein concentrate (MPC) was cooled to a temperature of $(4 \pm 2)^{\circ} \mathrm{C}$.

Malt is pre-soaked, sprouted in artificial conditions and enriched with active enzymes grains of various types of crops [12,13]. Malt production was carried out in the following sequence: water was collected in a malt-growing box to half its volume, and grains were poured into the water. After mixing, water was added to the full volume of the apparatus and the alloy was removed through a drain box. The washed grains were soaked in an air-water way until the desired moisture content for oats was reached $42-43 \%$; for wheat $-44-46 \%$; for corn - 44-46\%; for barley - 43-45\%. Germination of soaked grains was carried out at a temperature of $16-18{ }^{\circ} \mathrm{C}$ for 3-7 days, depending on the cereal, wheat $-3-4$ days, oats - 56 days, corn $-7-8$ days, barley $-6-7$ days. The grain was mixed and blown with air using a fan to aerate and maintain the desired temperature during germination. Grain was dried in warmed up air heated in a heater with a gradual increase in temperature from 30 to $75{ }^{\circ} \mathrm{C}$. Ready sprouted grains were unloaded at the plant and sent for grinding [14-19]. Sprouted grains contain a sufficient set of ingredients necessary for a balanced diet - proteins, carbohydrates which are easily digested, dietary fiber, minerals, vitamins and others. During the development of the embryo, various enzymes are activated, which turn insoluble compounds (starch, protein) into soluble (saccharides, amino acids, etc.). In addition, cereal malt contains coloring and polyphenolic compounds, as well as plant enzymes and hormones [13].

Milk-protein concentrates with malt ingredients were obtained by introducing $5.0 \%$ of various malt into the base - wheat, barley, oat, and corn. The quantity was based on observing the principle of preserving the corresponding organoleptic characteristics, which characteristic for traditional MPC with fillers.

\section{Methods}

Order of the research. To study the biological value of milk-protein concentrates with malt ingredients, their amino acid composition has determined by ion-exchange chromatography. Researches have performed on an automatic analyzer LC 3000 of the company «Eppendorf-Biotronic» (Germany). Control sample - MPC with a moisture content $(78 \pm 2) \%$, made by classical technology without the addition of malt. Hydrolysis of the sample has realized with a solution of $6 \mathrm{~N}$ hydrochloric acid, at a temperature $(120 \pm 2){ }^{\circ} \mathrm{C}$ for 24 hours. This method allows to determine with accuracy to $\pm(5-10) \%$ the presence of up to 18 amino acids with a minimum level of their content in solution $(0,500 \pm 0,006)$ $\mu \mathrm{mol} / \mathrm{ml}[20]$.

The amino acid content in milk-protein concentrates with malt ingredients (wheat, barley, oat, corn) was compared with their amount in the control sample - milk protein concentrate obtained by the acid-rennet method that was described above.

The biological value of milk protein concentrates without and with malt ingredients has been determined by calculating the following indicators.

Amino acid score (AAS, \%), which is defined as the ratio of the mass fraction of each essential amino acid in the product (EAA $\mathrm{pr}, \mathrm{g} / 100 \mathrm{~g}$ protein) to the corresponding essential ideal acid amino acid $\left(\mathrm{EAA}_{\mathrm{id}}, \mathrm{g} / 100 \mathrm{~g}\right.$ protein) on the amino acid scale recommended by FAO/WHO [21-23]. 
Amino acid score has been calculated by the formula:

$$
C_{j}=\frac{A_{j}}{A_{e j}} \cdot 100
$$

where $A_{j}$ - mass fraction of the $j$-th acid EAA in the sample, $g / 100 \mathrm{~g}$ of protein; $A_{e j}$ - the mass fraction of the $\mathrm{j}$-th acid of EAA, in standart, the proportion of the physiologically necessary standard for a certain consumer group, $\mathrm{g} / 100 \mathrm{~g}$ of protein.

Utilitarian coefficient of the amino acid composition of the product (U) numerically characterizes the balance of all EAA proteins with respect to the standard, or physiological norm, and is used to compare the protein composition of various food products based on their amino acid composition and inadequacy of their use in the body.

Utilitarian coefficient has been calculated by the formula:

$$
U=C_{\min } \frac{\sum_{j=1}^{8} A_{e j}}{\sum_{j=1}^{8} A_{j}}
$$

where $A_{e j}$ - mass fraction of the $j$-th acid EAA in the standard, $m g / g$ of protein; $A_{j}-$ mass fraction of the $\mathrm{j}$-th acid EAA in the product protein, $\mathrm{mg} / \mathrm{g}$ of protein; $\mathrm{C}_{\min }$-score of the first limited acid EAA, units;

Redundancy coefficient $\left(\sigma_{\text {red }}\right)$ - shows the mass fraction of EAA in $100 \mathrm{~g}$ product, which is not fully used by the body.

$$
\sigma_{\text {red }}=\frac{\sum_{j=1}^{k}\left(A_{j}-C_{m i n} A_{e j}\right)}{C_{\min }}
$$

Differential coefficient of amino acid score (DCAS) and the biological value of protein (BC) - according to the method of M.P. Chernikov. It is based on the postulate that the assimilation of EAA is limited by the content of the limiting amino acid. That is, all of their excess goes to energy needs, but not to protein biosynthesis. The average excess amino acid excess EAA in comparison with the smallest AAS of the limiting amino acid, DCAS has been found by the formula:

$$
D C A S=\frac{\sum \Delta D A S}{n},
$$

where DAS - the difference in amino acid score for each EAA compared to the AS of a limiting amino acid, $\% ; \mathrm{n}-$ the number of amino acids.

The lower the DCAS value, the more fully EAA is used for the needs of biosynthesis. Biological value of the producthas been calculated by the formula, $\%$ :

where, BV - Biological value of the protein, $\%$.

$$
B V=100-D C A S \text {, }
$$


During the assessment of biological value, it is very important to assess the level of mutual balance between the EAA and the NAA protein product, which is based on 4 biomedical positions:

1. The assimilation of the EAA protein product is carried out by the body: for the anabolic needs for the body (nitrogen balance restoration, the synthesis of special proteins) synthesis of NAA, for the energy needs of the body.

2. The use of EAA products for anabolic needs is a priority for the body compared to using them as precursors of NAA biosynthesis and to compensate for energy costs.

3. Due to imbalance, insufficiency or excess of EAA through degradation, they can be spent on the biosynthesis of interchangeable amino acids and energy purposes.

4. From the amount of EAA of the product for anabolic needs can be used a part that is proportional to the level of the first limited EAA, the score of which is calculated according to a reasonable norm, taking into account the physiological specificity of a consumers specific group. This fraction of EAA is the rationality coefficient of the amino acid composition of $\mathrm{R}_{\text {rat }}$ protein products and is calculated by the formula:

$$
R_{\text {rat }}=\sum_{j=1}^{k} E A A^{a n a b}=\sum_{j=1}^{k} A_{j} \cdot \mathrm{U}_{j},
$$

where $A_{j}$ - mass fraction of the $j$-th acid EAA in the product protein, $m g / g$ of protein; $U_{j}-$ utilitarian coefficient of the $\mathrm{j}$-th EAA of protein, share units.

The other EAA will be used by the body either as precursors of the biosynthesis of NAA, or as energy material. Their distribution depends on the ratio between the amounts of EAA and NAA in the product, and the level of EAA in the regulatory protein.

In symbolic form, the provisions set forth can be written in a certain way:

$$
\left\{\mathrm{R}_{\text {rat }} \rightarrow \max \sum^{\text {biosy nthesi NAA }} \mathrm{EAA} \rightarrow \min ; \sum^{\text {energyconsumption }} \mathrm{EAA} \rightarrow \min \right\}
$$

To assess the level of mutual balance between EAA and NAA in the product protein, 5 mutually exclusive options can be distinguished.

The following designations are introduced: $\Sigma$ EAA - the total mass fraction of EAA in the evaluated protein; $\Sigma \mathrm{E}-$ is the total mass fraction of EAA in the reference protein; $\mathrm{U} \cdot \Sigma \mathrm{EAA}$ - mass fraction of EAA mutual balance.

1. $\mathrm{U}=1 ; \Sigma \mathrm{EAA}>\Sigma \mathrm{E} ; \mathrm{C}_{\min }>1$;

2. $\mathrm{U}=1 ; \Sigma \mathrm{EAA} \leq \Sigma \mathrm{E} ; \mathrm{C}_{\min }<1$;

3. $\mathrm{U}<1 ; \Sigma \mathrm{EAA}>\Sigma \mathrm{E} ; \mathrm{C}_{\min } \geq 1 ; \Sigma \mathrm{EAA} \cdot \mathrm{U} \geq \Sigma \mathrm{E}$;

4. $\mathrm{U}<1 ; \Sigma \mathrm{EAA} \geq \Sigma \mathrm{E} ; \mathrm{C}_{\min }<1 ; \Sigma \mathrm{EAA} \cdot \mathrm{U} \cdot<\Sigma \mathrm{E}$;

4a. $1-\Sigma \mathrm{EAA} \geq(1-\Sigma \mathrm{E}) \cdot \mathrm{C}_{\min }$;

46. $1-\Sigma \mathrm{EAA}<(1-\Sigma \mathrm{E}) \cdot \mathrm{C}_{\min }$

5. $\mathrm{U}<1 ; \Sigma \mathrm{EAA}<\Sigma \mathrm{E} ; \mathrm{C}_{\min }<1$.

The integral score of products was determined by the A. Pokrovsky balanced nutrition formula $[24,25]$.

The product composition in terms of energy value, corresponds to $300 \mathrm{kcal}$ (10\% of daily energy costs), has been compared with the ideal composition of the daily human diet and expressed as a percentage.

In vitro digestibility (attackability) of proteins has been determined by an improved method A.A. Pokrovsky [26]. The essence of the method is to create conditions similar to the conditions of the gastrointestinal tract of the human body. The protein was hydrolyzed under 
the action of a protease system: pepsin and trypsin. The hydrolyzed product was diverted through a semipermeable membrane. The amount of protein in the resulting mixture have been determined by the Kjeldahl method. The obtained values are the digestibility of the protein of the studied product, expressed in $\mathrm{mg}$ of tyrosine per $1 \mathrm{~g}$ of protein. Recalculation of the indicator in percent is carried out according to the formula:

$$
D_{p r}=\frac{10 \cdot D}{T} \text {, }
$$

where $\mathrm{D}_{\mathrm{pr}}$ - the digestibility of the protein in the test product, $\%$ of the initial mass fraction of tyrosine in the product; $\mathrm{D}$ - the digestibility of the protein in the test sample, expressed in $\mathrm{mg}$ of tyrosine/1 $\mathrm{g}$ of protein; $\mathrm{T}$ - mass fraction of tyrosine in the protein of the test object, $\mathrm{g} / 100 \mathrm{~g}$ of protein; 10 - proportionality coefficient.

Biological value research of milk-protein concentrates with malt ingredients will justify the feasibility of their implementation in a production environment.

\section{Results and discussion}

\section{Determination of amino acid composition and biological value in milk-protein concentrates}

Researches have shown that the total amino acid content in milk protein concentrates with malt ingredients increased compared to control due to the addition of germinated cereals (wheat, barley, oats, corn) (Tables 1 and 2). The combination of these plant components with milk protein concentrate is likely to increase the biological value of such compositions.

Essential amino acids of milk-protein concentrates with malt ingredients

Table 1

\begin{tabular}{|c|c|c|c|c|c|}
\hline \multirow{4}{*}{ Indicator } & \multicolumn{5}{|c|}{ Milk-protein concentrate } \\
\hline & \multirow{2}{*}{$\begin{array}{l}\text { Control } \\
\text { sample }\end{array}$} & \multicolumn{4}{|c|}{ With malt ingredients } \\
\hline & & Wheat & Barley & Oat & Corn \\
\hline & \multicolumn{5}{|c|}{$\%$ to total amounts } \\
\hline \multirow{2}{*}{ Valine } & 870.30 & 918.27 & 914.05 & 906.39 & 885.63 \\
\hline & 5.77 & 5.97 & 6.05 & 6.00 & 5.95 \\
\hline \multirow{2}{*}{ Isoleucine } & 793.80 & 829.75 & $\underline{824.09}$ & 821.20 & 814.32 \\
\hline & 5.26 & 5.39 & 5.45 & 5.43 & 5.47 \\
\hline \multirow{2}{*}{ Leucine } & 1491.61 & 1579.47 & 1562.71 & 1559.83 & 1569.26 \\
\hline & 9.88 & 10.26 & $\overline{10.34}$ & 10.32 & 10.54 \\
\hline \multirow{2}{*}{ Lysin } & 1159.37 & 1199.06 & 1202.50 & 1212.94 & 1184.41 \\
\hline & 7.68 & 7.79 & 7.96 & 8.02 & 7.95 \\
\hline \multirow{2}{*}{ Methionine } & 419.48 & 450.49 & 455.75 & 444.87 & 446.28 \\
\hline & 2.78 & 2.93 & 3.02 & 2.94 & 3.00 \\
\hline \multirow{2}{*}{ Threonine } & 599.35 & 641.70 & 636.04 & 643.66 & 631.83 \\
\hline & 3.97 & 4.17 & 4.21 & 4.26 & 4.24 \\
\hline \multirow{2}{*}{ Tryptophan } & 261.12 & 260.86 & 260.86 & 260.86 & 260.86 \\
\hline & 1.73 & 1.69 & 1.73 & 1.73 & 1.75 \\
\hline \multirow{2}{*}{ Phenylalanine } & 822.22 & 884.45 & $\underline{871.79}$ & 874.35 & 856.47 \\
\hline & 5.45 & 5.75 & $\overline{5.77}$ & 5.78 & 5.75 \\
\hline \multirow{2}{*}{ Amount } & 6417.25 & 6764.05 & $\underline{6727.80}$ & 6724.09 & 6649.06 \\
\hline & 42.51 & 43.94 & 44.53 & 44.48 & 44.64 \\
\hline
\end{tabular}


Table 2

Nonessential amino acids of milk-protein concentrates with malt ingredients

\begin{tabular}{|c|c|c|c|c|c|}
\hline \multirow{4}{*}{ Indicator } & \multicolumn{5}{|c|}{ Milk-protein concentrate } \\
\hline & \multirow{2}{*}{$\begin{array}{l}\text { Control } \\
\text { sample }\end{array}$} & \multicolumn{4}{|c|}{ With malt ingredients } \\
\hline & & Wheat & Barley & Oat & Corn \\
\hline & \multicolumn{5}{|c|}{ \% to total amounts } \\
\hline \multirow{2}{*}{ Alanine } & 400.74 & 402.37 & 411.87 & 414.47 & 425.77 \\
\hline & 2.65 & 2.61 & 2.73 & 2.74 & 2.86 \\
\hline \multirow{2}{*}{ Arginine } & 668.31 & 655.68 & 650.38 & 655.04 & 621.98 \\
\hline & 4.43 & 4.26 & 4.31 & 4.33 & 4.18 \\
\hline \multirow{2}{*}{ Asparlic acid } & 897.48 & 874.54 & 862.64 & 911.21 & 866.24 \\
\hline & 5.95 & 5.68 & 5.71 & 6.03 & 5.82 \\
\hline \multirow{2}{*}{ Histidin } & 477.24 & 455.51 & 448.91 & 444.71 & 445.79 \\
\hline & 3.16 & 2.96 & 2.97 & 2.94 & 2.99 \\
\hline \multirow{2}{*}{ Glycine } & 239.16 & 264.44 & 251.84 & 262.54 & 245.44 \\
\hline & 1.58 & 1.72 & 1.67 & 1.74 & 1.65 \\
\hline \multirow{2}{*}{ Glutamic acid } & 2718.72 & 2788.95 & 2617.35 & 2644.55 & 2598.15 \\
\hline & 18.01 & 18.12 & 17.32 & 17.49 & 17.44 \\
\hline \multirow{2}{*}{ Proline } & 1596.21 & 1567.39 & 1549.79 & 1452.09 & 1475.19 \\
\hline & 10.57 & 10.18 & 10.26 & 9.61 & 9.90 \\
\hline \multirow{2}{*}{ Serine } & 744.19 & 730.57 & 710.57 & 724.37 & 706.47 \\
\hline & 4.93 & 4.75 & 4.70 & 4.79 & 4.74 \\
\hline \multirow{2}{*}{ Tyrosine } & 837.89 & 783.40 & 777.40 & 781.30 & 766.50 \\
\hline & 5.55 & 5.09 & 5.15 & 5.17 & 5.15 \\
\hline \multirow{2}{*}{ Cystine } & 98.15 & 106.04 & 98.94 & 101.94 & 93.74 \\
\hline & 0.65 & 0.69 & 0.65 & 0.67 & 0.63 \\
\hline \multirow{2}{*}{ Amount } & 8678.09 & $\underline{8628.88}$ & $\underline{8379.68}$ & 8392.21 & 8245.26 \\
\hline & 57.49 & 56.06 & 55.47 & 55.52 & 55.36 \\
\hline
\end{tabular}

The compliance degree of the EAA content in the product with the FAO/WHO amino acid scale is calculated by the amino acid score $\left(\mathrm{C}_{\mathrm{j}}, \%\right)$, which shows by which EAA (one, two or more) studied protein is limited $[3,5,6]$. The amino acid score for the studied samples has been calculated. The obtained data indicate that the first limiting amino acids of the control and milk-protein concentrates with malt ingredients are methionine and cystine [7]. Moreover, the amino acid score of MPC obtained by traditional technology is $97.97 \%$. This means that, in general, the norms of EAA MPC by the human body can fully use the following amount of amino acids [5], which is calculated by the formula:

$$
\sum E A A=0.9897 \cdot \sum_{j=1}^{k} A_{e j},
$$

where $\sum E A A$ - the full-fledged portion of the EAA in the product protein, $\mathrm{g} / 100 \mathrm{~g} ; \mathrm{A}_{\mathrm{ej}}{ }^{-}$ the amount of the $\mathrm{j}$-th EAA in the ideal protein, $\mathrm{g} / 100 \mathrm{~g}$. 
According to the calculations, when preparing the mixture: milk-protein concentrate + malt ingredients, the content of limiting amino acids increases - methionine + cystine and threonine. Liquidation of their deficit leads to an increase in the degree of use other EAA in milk protein concentrate to restore nitrogen balance and the synthesis of special proteins [1]. The amino acid score of the first limiting amino acids in milk-protein concentrates with malt ingredients is presented in Figure 1.

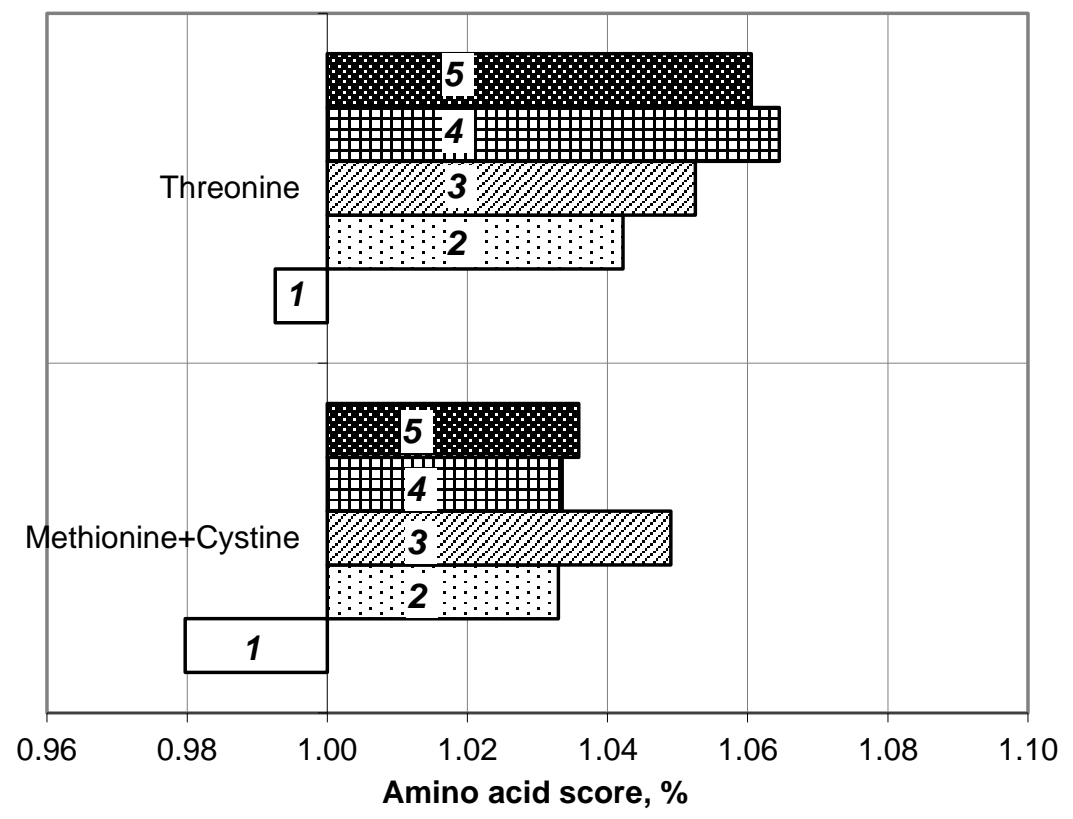

Figure 1. Amino acid score of the first limiting amino acids in:

milk-protein concentrate (control sample) (1) and milk-protein concentrates with malt ingredients - wheat (2), barley (3), oat (4), corn (5).

The score of each amino acid gives a general idea about biological value of the product [3]. The body's use of protein for anabolic needs is limited by the content of the limiting amino acid, and all excess of other essential substances is used to compensate for the energy consumption and biosynthesis of NAA [4]. To assess the degree of protein utilization, the differential coefficient of amino acid score (DCAS) has been determined - the average excess amino acid scores of essential amino acids compared to score of limiting amino acid. The less DCAS, the more fully amino acids are used in the product. According to the theory of P. Chernikov, the indicator DCAS can be used to compare the biological value of food proteins [2].

Analyzing the obtained data of milk-protein concentrates with malt ingredients, we can conclude that the biological value of the experimental samples is increased. So, with wheat malt this indicator is $65.82 \%$, barley $-65.57 \%$, oat $-64.11 \%$, corn $-63.95 \%$, while for control purposes the value is fixed at $62.84 \%$.

Balance assessment of the amino acid composition of proteins in milk-protein concentrates with malt ingredients is presented in Figure 2. 


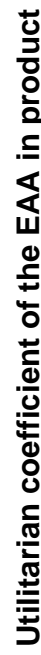
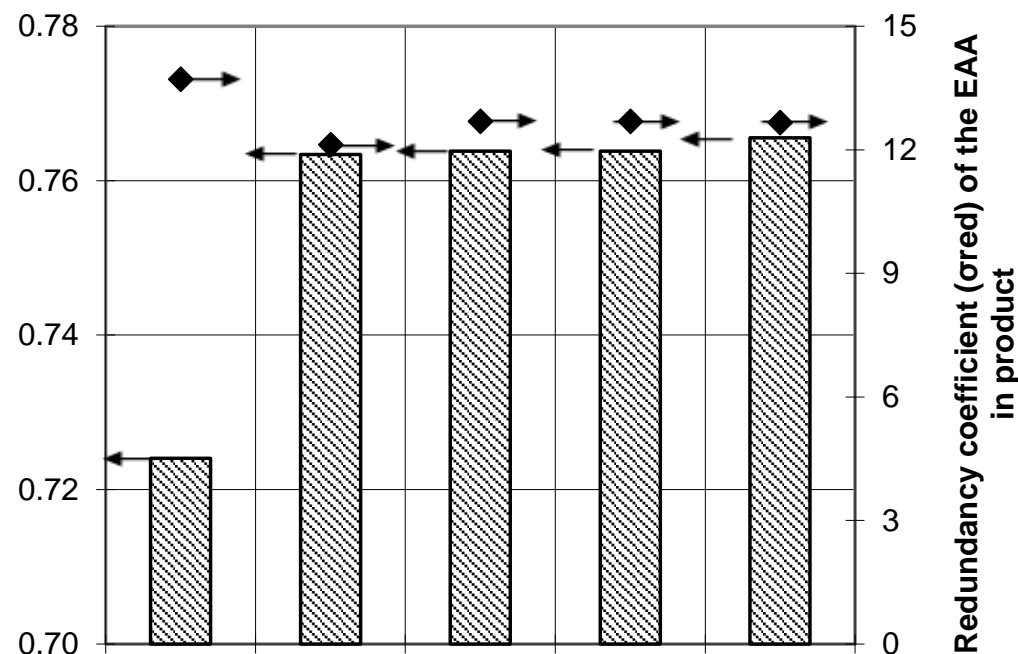

1

3

5

UUtilitarian coefficient of the EAA in product (U)

- Redundancy coefficient (ored) of the EAA in product

a

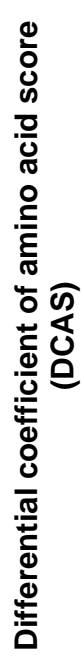

$$
\begin{aligned}
& 37.5 \\
& 37.0 \\
& 36.5 \\
& 36.0 \\
& 35.5 \\
& 35.0
\end{aligned}
$$

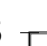

36.5

36.0

34.5

34.0

33.5

33.0

32.5
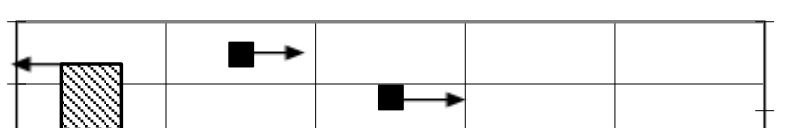

66.0

65.5

65.0

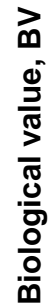

63.5

63.0

1

2

3

4

5

\$Differential coefficient of amino acid score, (DCAS)

-Biological value, BV

b

Figure 2. Balance assessment of the amino acid composition of proteins in (a, b): milk-protein concentrate (control sample) (1) and milk-protein concentrates with malt ingredients - wheat (2), barley (3), oat (4), corn (5). 
According to the data (Figure 2), utilitarian coefficient compared with the control sample (0.72) increases and lies in the range $0.76-0.78$ for milk-protein concentrates with malt ingredients, and the redundancy coefficient decreases from 13.72 (control sample) to 11.98. For model samples with barley malt, a high utilitarian coefficient $(0.78)$ and a low redundancy coefficient (11.98) have been found, which indicates about better balance of EAA and their effective utilization.

According to five mutually exclusive options (formulas 8-12), the rationality coefficient of the amino acid composition has been calculated $-\mathrm{R}_{\text {rat }} ; \Sigma \mathrm{EAA}_{\text {bios }} ; \Sigma \mathrm{EA} \mathrm{A}_{\text {energ }}$. MPC (control sample) can be estimated by the fourth option $($ Rrat $=U$ ), and sample with malt ingredients - by the third option $\left(\mathrm{R}_{\mathrm{rat}}=\mathrm{U} / \mathrm{C}_{\mathrm{min}}\right)$ [23-25]. Consequently, the rationality coefficient of amino acid composition is $0.74 \pm 0.12$, which is $3 \%$ higher than MPC obtained by traditional technology without malt.

It has found that the introduction of malt ingredients in MPC in the indicated amounts allows replacing part of the protein of animal origin with vegetable, without affecting the quality of the base. In addition, the developed milk protein concentrates with malt ingredients have an increased biological value compared to traditional ones, have dietary and preventive properties due to dietary fiber, macro- and microelements. In general, the research contributes to the rationale for malt using in the production of multicomponent milk-protein products of functional purpose.

\section{In vitro digestibility of proteins}

Correlation dependence between the biological value of proteins and their amino acid composition is possible only if the digestion rate of proteins is sufficient for digestive tract enzymes [27]. In this regard, for determining the nutritional value of milk protein concentrates with malt ingredients, an in vitro attacked protein complex of proteolytic enzymes, pepsin and trypsin, has been studied. The obtained results on the example of milk protein concentrate (control samples) without and with wheat malt are presented in Figure 3.

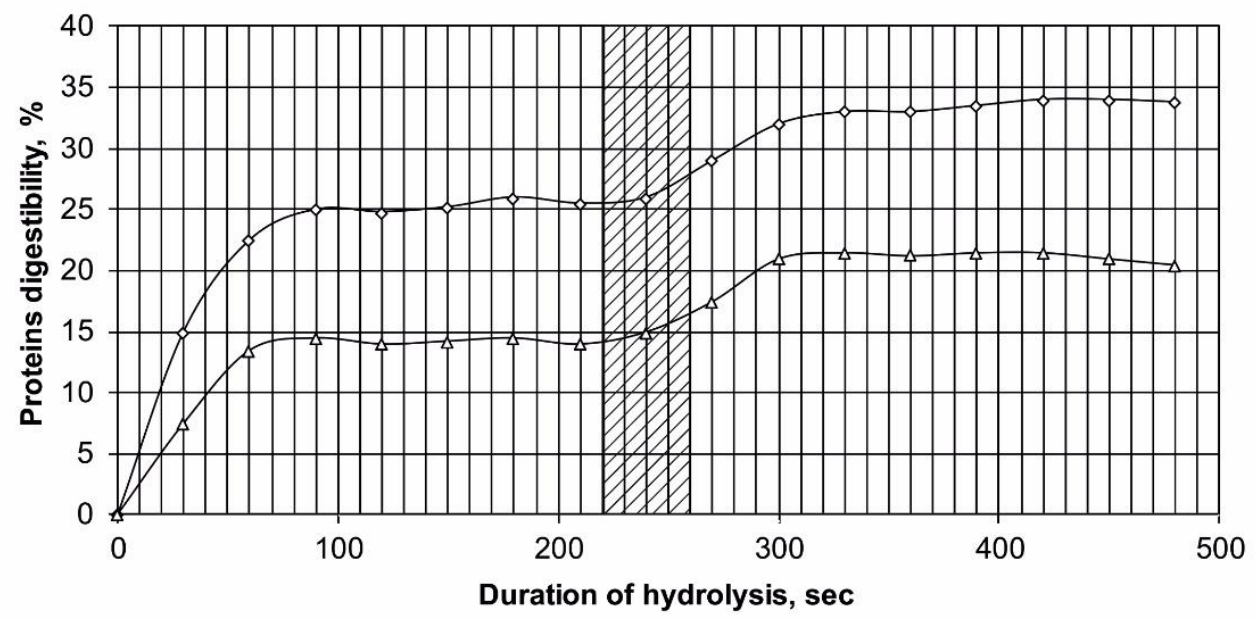

$\leadsto$ milk-protein concentrate (control sample) $\rightarrow-$ milk-protein concentrate with wheat malt

Figure 3. Proteins digestibility by the enzyme system "pepsin + trypsin":

1 - milk-protein concentrate (control sample), 2 - milk-protein concentrate with wheat malt.

Note. The selected fragment indicates the moment of trypsin administration. 


\section{Food Technology}

According to experimental data, the in vitro digestibility of proteins under the action of enzymes (pepsin + trypsin) with the introduction of malt ingredients in milk protein concentrates is accelerated. This is due to previous hydrolysis and destruction of protein substances during malting of cereals.

The represented data indicate that all samples are easily hydrolyzed. The resulting graphical dependencies have a similar tendency: the process in pepsin and trypsin stages most rapidly occurs in the first hour. The hydrolysis of MPC proteins after preliminary digestion with pepsin is accompanied by the release of the largest number of amino acids. Immediately after the trypsin is added to the system, the concentration of amino acids sharply increases and continues to increase continuously and intensively during the second stage of the experiment.

\section{Conclusions}

Amino acid composition and biological value, the balance of the amino acid composition of proteins in milk-protein concentrates with malt ingredients has determined by high-chromatography method.

The biological value of milk protein concentrates is increased for research samples with wheat malt by $2.98 \%$, barley $-2.73 \%$, oat $-1.27 \%$, corn $-1.11 \%$ compared with the classic milk protein concentrate.

The rationality coefficient of amino acid composition for all research samples is $0.74 \pm 0.12$, which is $3 \%$ higher than MPC obtained by traditional technology.

According to the classification of A. Pokrovsky all samples of milk-protein concentrates can be attributed to the first group of food products with a high degree of protein in vitro digestibility under the action of enzymes (pepsin + trypsin).

The introduction of malt ingredients in the amount of $5 \%$ by weight of MPK allows replacing part of the protein of animal origin with vegeTable, without affecting the quality of the base.

The developed milk protein concentrates with malt ingredients have dietary and preventive properties due to dietary fiber, macro- and microelements.

In general, the research contributes to the rationale for malt using in the production of multicomponent milk-protein products of functional purpose.

\section{References}

1. Yudina T., Nazarenko I. (2014), Biological value study for milk-plant minced masses from buttermilk concentrate, The Advanced Science Journal, 2, pp. 70-73.

2. Gil Á., Martinez de Victoria E., Olza J. (2015), Indicators for the evaluation of diet quality, NutricionHospitalaria, 26(3), pp. 128-44.

3. World Health Organization (2007), Protein and amino acid requirements in human nutrition, World Health Organization, Geneva, Available at: https://apps.who.int/iris/bitstream/handle/10665/43411/WHO_TRS_935_eng.pdf?ua= 1 .

4. Moore D., Soeters P. (2015), The Biological Value of Protein, NestlÃ Nutrition Institute workshop series, 82, pp. 39-51. 


\section{- Food Technology}

5. FAO Expert Consultation, (2013), Dietary protein quality evaluation in human nutrition, FAO, Rome. Available at: http://www.fao.org/ag/humannutrition/3597802317b979a686a57aa4593304ffc17f06.pdf.

6. Ryzhkova T., Bondarenko T., Dyukareva G., Biletskaya Y. (2017), Development of a technology with an iodine-containing additive to produce kefir from goat milk, EasternEuropean Journal of Enterprise Technologies, 3/11 (87), pp. 37-44.

7. Pacheco L., Sakomura N., Suzuki R., Dorigam Ju., Viana G., Milgen J., Denadai Ju. (2018), Methionine to cystine ratio in the total sulfur amino acid requirements and sulfur amino acid metabolism using labelled amino acid approach for broilers, $B M C$ Veterinary Research, 14 (1), pp. 364-375.

8. Lutters E., Houten F., Bernard A., Mermoz E., Schutte C. (2014), Tools and techniques for product design, CIRP Annals - Manufacturing Technology, 63, pp. 607-630.

9. Gorissen S.H.M., Crombag J.J.R., Senden J.M.G. Waterval W.A.H., Bierau J., Verdijk L.B. (2018), Protein content and amino acid composition of commercially available plant-based protein isolates, Amino Acids, 50(12), pp. 1685-1695.

10. Onopriychuk O., Grek O., Tymchuk A. (2015), Optimization of the composition of the mixture by simplex method, Ukrainian Food Journal, 4(1), pp. 49-58.

11. Castro I., Silva R., Tirapegui J., Borsato D., Bona E. (2017), The Use of a Simplex Method with an Artificial basis in Modeling of Flour Mixtures for Bakery Products, International Journal of Advanced Computer Science and Applications, 8(12), pp. 338344.

12. Kovalova O., Chursinov Y., \&Kofan D. (2019), Research of hydrothermal processing of dry barley malt, Grain Products and Mixed Fodder's, 18(4), pp. 13-18.

13. Korotkikh E.A., Chusova A.E., Novikova I.V., AstafevaIu.E. (2014), Sposobpolucheniiapolisolodovogoekstrakta, Pivoinapitki, 1, pp. 8-10.

14. Agafonov G. V. (2014), Biotekhnologiia poroshkoobraznykh solodovykh ekstraktov na osnove netraditsionnogo syria i proektirovanie napitkov s funktsionalnymi svoistvami, IPTs «Nauchnaiakniga», Voronezh.

15. Faltermaier A., Waters D., Becker T., Arendt E., Gastl M. (2014), Common wheat (Triticumaestivum L.) and its use as a brewing cereal - a review, Journal of the Institute of Brewing, 120 (1), pp. 1-15.

16. Khuzin F., Kanarskaia Z., Ivleva A., Gematdinova V. (2017), Sovershenstvovanie tekhnologii proizvodstva khlebobulochnogo izdeliia na osnove izmelchennogo prorosshego zerna pshenitsy, Vestnik VGUIT, 79(1), pp. 178-187.

17. Nevskayaa E.V., Borodulinb D.M., Potekhac V.L., Nevskiya A.A., Lobasenkob B.A., Shulbaevab M.T. (2018), Development of integrated technology and assortment of long-life rye-wheat bakery products, Foods and Raw Materials, 6(1), pp. 99-109.

18. Onopriichuk O.O., Grek O.V. (2008), Analiz biolohichnoi tsinnosti syrkovykh vyrobiv iz zernovymy inhrediientamy, Tavriiskii naukovii visnik, 56, pp. 139-145.

19. Balcerek M., Pielech-Przybylska K., Dziekońska-Kubczak U., Patelski P., Strąk E. (2016), Fermentation Results and Chemical Composition of Agricultural Distillates Obtained from Rye and Barley Grains and the Corresponding Malts as a Source of Amylolytic Enzymes and Starch, Molecules, 21(10), pp. 1320-1339.

20. Rybak O. (2014), The role of milk proteins in the structure formation of dairy products, Ukrainian Food Journal, 3(3), pp. 350-360.

21. Marinangeli C., House J. (2017), Potential impact of the digestible indispensable amino acid score as a measure of protein quality on dietary regulations and health, Nutrition Reviews, 75(8), pp. 658-667. 
22. Olga Rybak (2016), Milk fat in structure formation of dairy products: a review, Ukrainian Food Journal, 5(3), pp. 499-514.

23. Burd N., McKenna C., Salvador A., Paulussen K., Moore D. (2019), Dietary Protein Quantity, Quality, and Exercise Are Key to Healthy Living: A Muscle-Centric Perspective Across the Lifespan, Frontiers in Nutrition, 6 (83), pp. 1-12.

24. Usenkoa N., Khlestkinaa E., Asavasantic S., Gordeevab E., Yudinab R., Otmakhovad Yu. (2018), Possibilities of enriching food products with anthocyanins by using new forms of cereals, Foods and Raw Materials, 6, pp.128-134.

25. Simakhina G., Naumenko N., Yarosh K. (2015), New non-traditional sources of food protein, Ukrainian Food Journal, 4 (3), pp. 453-459.

26. Bryan D., Abbott D., Classen H. (2018), Development of an in vitro protein digestibility assay mimicking the chicken digestive tract, Animal Nutrition, 4(4), pp. 401-409.

27. Tavano O., Berenguer-Murcia A., Secundo F., Fernandez-Lafuente R. (2018), Biotechnological Applications of Proteases in Food Technology, Comprehensive Reviews in Food Science and Food Safety, 17, pp. 412-436. 